\title{
Fluidized bed treatment of rapeseed meal and cake as possibility for the production of canolol
}

\author{
Frank Pudel $^{1, \star}$, Volkmar Habicht ${ }^{1}$, Thomas Piofczyk ${ }^{1}$, Bertrand Matthäus $^{2}$, Karl-Werner Quirin $^{3}$ \\ and Anja Cawelius ${ }^{3}$ \\ 1 Pilot Pflanzenöltechnologie Magdeburg e.V., Magdeburg, Germany \\ 2 Max-Rubner-Institut, Detmold, Germany \\ 3 Flavex Naturextrakte GmbH, Rehlingen, Germany
}

Received 27 September 2013 - Accepted 14 October 2013

\begin{abstract}
Canolol (2,6-dimethoxy-4-vinylphenol, 4-vinylsyringol), which is formed by thermally initiated $\mathrm{CO}_{2}$ splitting off from sinapic acid, possesses a high antioxidant potential. Furthermore different positive physiological properties are described. Due to rapeseed's high content of phenolic acids, particularly sinapic acid, it is obvious to produce canolol as by-product of rapeseed processing. Roasting of rapeseed meal or cake in a fluidized bed followed by extraction with supercritical carbon dioxide of the formed canolol represents a production procedure which not impairs the commercial oil mill process. This article summarizes results from the roasting process with rapeseed meal and cake in fluidized bed equipments of different design and size showing that it is a suitable technique to transform sinapic acid into canolol. The achieved canolol contents are at $500 \mathrm{mg} / \mathrm{kg}$ in minimum, if the material is rapidly cooled-down after reaching the optimal temperature of $165^{\circ} \mathrm{C}$. Further roasting leads to a fast reduction of the canolol content. In addition it could be observed, that the sinapic acid content is not decreasing in the same amount as the canolol content increases. Sinapic acid seems to be "reproduced" during roasting. The reaction mechanisms of the described phenomena are not known.
\end{abstract}

Keywords: Rapeseed / canolol / fludized bed / roasting / antioxidant

Résumé - Chauffage des tourteaux ou farines de graines sur un lit fluidisé : une possibilité de production de Canolol. Le canolol (2,6-dimethoxy-4-vinylphenol, 4-vinylsyringol), qui se forme, sous l'effet de la chaleur, par détachement d'une molécule de $\mathrm{CO}_{2}$ de l'acide sinapique, possède un haut pouvoir antioxydant. De plus, des propriétés physiologiques bénéfiques ont été décrites. En raison du haut contenu de la graine de colza en acides phénoliques, et particulièrement en acide sinapique, il semble relativement évident de chercher à produire du canolol en tant que sousproduit du traitement de graine de colza. Le chauffage des tourteaux ou farines de graines de colza sur un lit fluidisé suivi par l'extraction, avec du dioxyde de carbone supercritique, du canolol formé représente une procédure de production qui ne détériore pas le processus des triturateurs d'huile. Cet article récapitule les résultats du processus de chauffage des tourteaux et farines de graines de colza dans des lits fluidisés de conception et de taille différentes, démontrant que c'est une technique appropriée pour transformer l'acide sinapique en canolol. Le contenu en canolol produit est au minimum de $500 \mathrm{mg} / \mathrm{kg}$, si la matière est rapidement refroidie après avoir atteint la température optimale de $165^{\circ} \mathrm{C}$. Des chauffages supplémentaires conduisent à une réduction rapide du contenu en canolol. De plus il pourrait être observé que le contenu en acide sinapique ne décroit pas dans la même proportion que les augmentations de contenus de canolol. L'acide semble être « reproduit » pendant le chauffage. On ne connaît pas les mécanismes des réactions en jeu dans les phénomènes décrits.

Mots clés : Colza / canolol / lit fluidisé / chauffage / antioxydant

\section{Introduction}

In comparison to the most other kinds of oilseeds rapeseed contains considerably more phenolic acids (Naczk, 2002), existing in free, esterified or insoluble bounded form. About $15 \%$

\footnotetext{
^ Correspondence: pudel@ppm-magdeburg.de
}

are free phenolic acids, whereas up to $80 \%$ esterified acids can be found. The most important phenolic acid is sinapic acid, representing $90 \%$ of the free and between 70 to $97 \%$ of the esterified acids (Naczk et al., 1998). Besides sinapic acid also other phenolic acids can be found in rapeseed, like hydroxybenzoic acid, vanillic acid, ferulic acid, caffeic acid or 


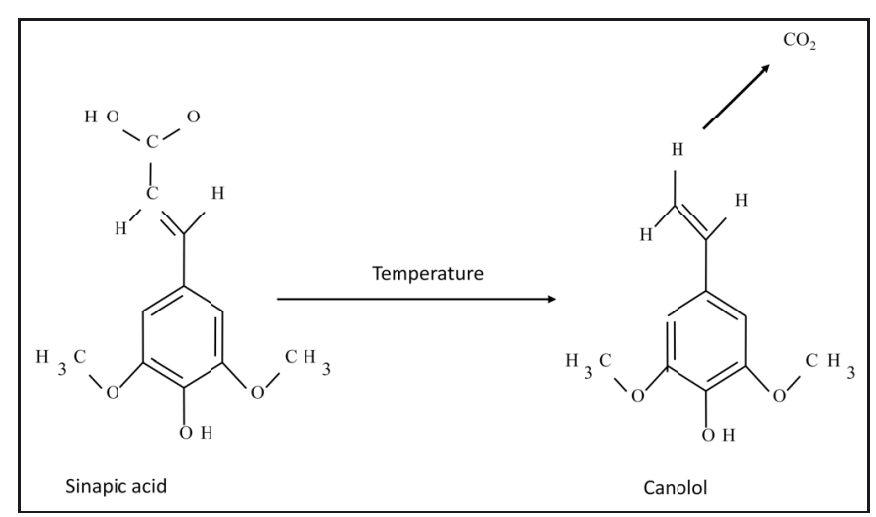

Fig. 1. Thermal transformation of sinapic acid into canolol.

protocatechol. Sinapine, an ester of sinapic acid and choline, is the main compound of the esterified phenolic acids, and in the literature contents between 0.6 and $2.5 \%$ are described (Baumert et al., 2005; Fenwick and Hoggan 1976; Müller et al., 1978). Artz et al. (1986) showed that the phenolic compounds are mainly localized in the cotyledons, whereas in the hulls only traces exist. Similar results for the distribution of sinapine in rapeseed were found by Krygier et al. (1982) and Matthäus (1998).

During oil extraction most of the phenolic compounds remain in the press cake or the meal and are not available for human consumption. But, within the cake or meal they are undesired, because they have a negative effect on the amino acid digestibility and sinapic acid leads to the formation of fishy smelling eggs in a particular kind of laying hen species (Qiao et al., 2008; Fenwick et al., 1984).

Koski et al. (2003) and Wakamatsu et al. (2005) showed that in crude rapeseed oil the oil soluble canolol (2,6-dimethoxy-4-vinylphenol, 4-vinylsyringol) as a degradation product of the hardly oil soluble sinapic acid can be found. Canolol is formed by $\mathrm{CO}_{2}$ splitting off from the sinapic acid and the reaction can be initiated by heat supply (Fig. 1).

In the literature different positive effects of canolol are described, like high antioxidant activity and antimutagenic and anticarcinogenic properties (Moltke-Sorensen et al., 2013; Matthäus, 2012; Kuwahara et al., 2004; Novak et al., 1992). In these investigations it was observed, that the antimutagenic properties of canolol are stronger than these of $\alpha$-tocopherol, B-carotene or vitamin $\mathrm{C}$ as well as different flavonoids like rutin or quercetin (Kuwahara et al., 2004). The antioxidant effect of sinapine, sinapic acid and canolol rich extracts as well as a not fractionated rapeseed polyphenol extract on oxidative stability of oil in water emulsions was investigated by Moltke Sørensen et al. (2013). The found order is BHT > canolol > sinapine $>$ total polyphenols $>$ sinapic acid.

Matthäus (2012) describes a clear antioxidant activity of canolol within a DPPH and B-carotene linolic acid assay, respectively, but lower than that of BHT or trolox. Nevertheless, the recovery of the natural antioxidant from rapeseed cake or meal is justified due to its distinctive bioactive effect.

Recently different approaches are taken in order to enrich canolol (and other phenolic compounds from rapeseed) within the oil or to isolate them.
A first one was roasting of rapeseed within an oven or by micro waves. Wakamatsu et al. (2005) observed an increase of the canolol content in the oil by 256 fold, if the seed is roasted for $5 \mathrm{~min}$ at a temperature of $165^{\circ} \mathrm{C}$. Spielmeyer et al. (2009) found a raise of canolol content in oil made from roasted rapeseed by 120 fold.

Another approach was taken by using high temperature conditioning of rapeseed before mechanical pressing, which leads to increased polyphenol contents in the crude oil (Eggers and Ambrogi, 2003). But, these contents will be considerably reduced again during subsequent refining (Eggers et al., 2006), in which the polyphenols are enriched in the deodorizer distillate. Thus, it was tried to isolate them by different process alternatives, like solvent extraction, short path distillation, supercritical $\mathrm{CO}_{2}$ extraction and solvent crystallization. As result polyphenol rich fractions could be recovered containing besides sinapic acid, vinylsiringol and its dimer also tocopherol and other substances (Eggers et al. 2010).

Alternatively it can be tried to treat rapeseed cake or meal after oil extraction thermally in order to transform the scarcely oil soluble sinapic acid into the oil soluble canolol and subsequent extracting it together with the remaining oil from the solid matter. The advantage of this approach is that the conventional oil mill process keeps untouched. Fluidized bed roasting promising an intensive heat treatment followed by a gentle and comprehensive extraction with supercritical $\mathrm{CO}_{2}$ should be suitable processes to realize that also in industrial scale. The use of meal instead of cake has the advantage of less remaining oil in the solid matter which has to be extracted leading to higher canolol contents in the oily extract. In the best case, the remaining extracted material should be suitable to be used in feed production.

A fluidized bed is a quantity of solid particles which are placed by a fluid under such conditions that the solid/fluid mixture behaves as a fluid. Under these conditions there is an intensive contact between the solid particles and the fluid, the equipment walls and possible installed heat exchangers as well as among themselves. This leads to very high heat and mass transfer coefficients and fast processing procedures. The temperature and concentration field within the equipment is homogenized. Fluidized bed equipments are wide used in different industries and provide a good up-scaling from lab to industrial scale.

In the following the roasting trials of rapeseed meal and rapeseed cake by fuidized bed treatment are described with its effect on the formation of canolol.

\section{Materials and methods}

\subsection{Materials}

As rapeseed meal different charges of commercial material were used. Before thermal treatment the meal was grinded by a roller mill (Co. Haferboy, gap width $0.8 \mathrm{~mm}$ ) and partially screened by sieving.

In one trial series rapeseed cake was used produced from commercial rapeseed by cold pressing within the PPM facilities. The cake was also grinded before roasting. 
Table 1. Canolol and sinapic acid.

\begin{tabular}{ccccc}
\hline $\begin{array}{c}\text { Compound- } \\
\text { name }\end{array}$ & CAS No. & Structure & $\begin{array}{c}\text { Molecular } \\
\text { formula }\end{array}$ & $\begin{array}{c}\text { Molecular } \\
\text { weight g/mol }\end{array}$ \\
\hline $\begin{array}{c}\text { Canolol, (4-Vinyl-2,6- } \\
\text { dimethoxyphenol) }\end{array}$ & {$[28343-22-8]$} & & & \\
\hline Sinapic Acid & {$[530-59-6]$} & $\mathrm{C}_{10} \mathrm{H}_{12} \mathrm{O}_{3}$ & 180.2 \\
\hline
\end{tabular}

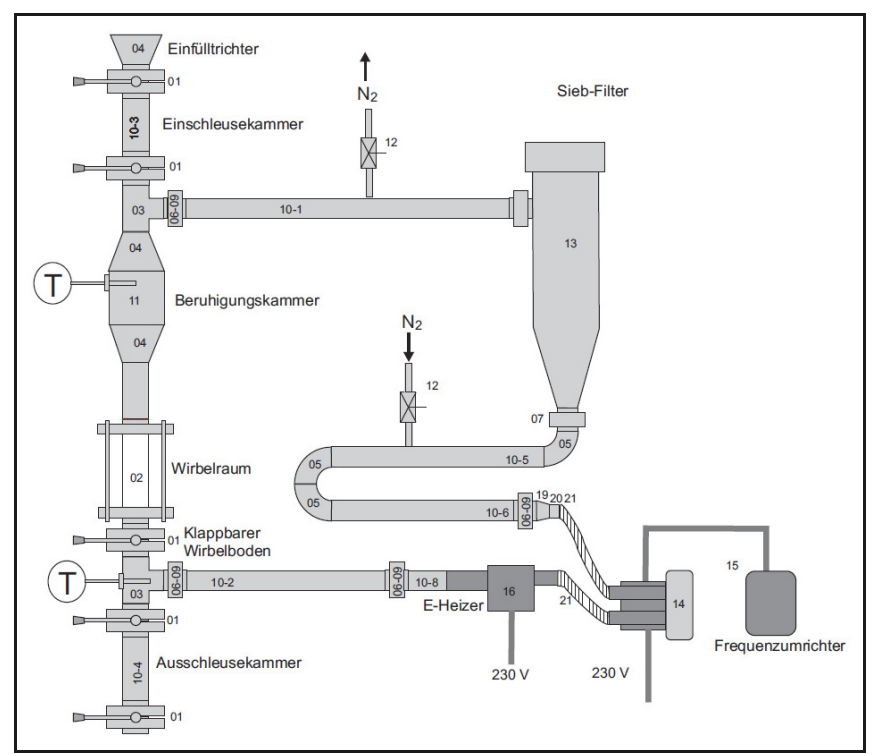

Fig. 2. Scheme of used lab and small pilot scale fluidized bed equipment.

\subsection{Methods}

Roasting of the raw material was carried out in fluidized bed equipments of different type and size.

The used lab and small pilot scale equipments (PPM facilities) are of the design shown in Figure 2. The material is fed batch wise top down into the fluidized bed reactor. At the bottom of the reactor a rotatable sieve plate was arranged. To intensify the roasting process the reactor was equipped with an electric trace heating system. The material was fluidized by a gas which was fed bottom up. Initially inert gas (nitrogen) was used, later on ambient air. The fluidization gas was heated by an electric heater and fed to the reactor by an air blower. To adjust the flow rate the air blower is frequency controlled. A settling chamber above the fluidized bed reactor made sure that discharged fine particles can fall back into the reactor. Residual fines were kept by a filter. After completion of roasting the sieve plate was turned and the material sampled beneath. In the lab scale equipment up to $400 \mathrm{~g}$ per batch can be treated, in the small pilot scale about $3 \mathrm{~kg}$ per batch.

In order to scale-up the process (as well as to recover sufficient material for subsequent extraction trials) two trials were made within a pilot scale equipment of Co. Allgaier, Uhingen, in which at a time $30 \mathrm{~kg}$ of meal per batch are treated (so called "industrial trials"). The reactor is equipped with pipe bundles immerging into the fluidized bed, what leads to additional heat input.

Finally, a set of trials in small pilot scale equipment at Otto-von-Guericke-University Magdeburg was carried out, in which superheated steam instead of a gas as fluidization medium was used. The hold-up was varied between 1.5 and $3 \mathrm{~kg}$ per batch.

\subsection{Analysis of canolol and sinapic acid}

To quantify canolol and sinapic acid (Tab. 1) in rapeseed extracts the following RP-DAD-HPLC method of external standard is used. A gradient method was developed. Canolol was detected at $280 \mathrm{~nm}$, sinapic acid at $325 \mathrm{~nm}$ (Tab. 2).

Sinapic acid (purity $>97 \%$ ) was purchased from Carl Roth $\mathrm{GmbH}$, Karlsruhe (Germany). Canolol is not commercially available as an analytical standard. Therefore, the compound was produced by thermal decarboxylation of pure sinapic acid ( $\sim 30 \mathrm{~min}$ at $220{ }^{\circ} \mathrm{C}$, under vacuum), canolol purity (HPLC) $80 \%$. Figure 3 shows the chromatogram of the standard materials.

To prepare the samples, rapeseed meal was milled to a fine powder and about 10-15 g were extracted by soxtherm extraction with methanol (equipment: Gerhardt, Soxtherm $2000 \mathrm{au}-$ tomatic). The extract solution was transferred into a $50 \mathrm{ml}$ flask and filled up to the mark with methanol. After filtration through a $0.45 \mu \mathrm{m}$ filter the sample was injected on the HPLC. Figure 4 shows the chromatogram of the extract.

The extract was dissolved in methanol. The turbidity of the solution was due to lipids insoluble in methanol. They were removed through a $0.45 \mu \mathrm{m}$ PTFE-filter and the clarified solution was directly used for HPLC. The extract concentration should be near to $5-10 \mathrm{mg} / \mathrm{ml}$.

The concentration of each component was determined by the following formulas:

$$
\begin{aligned}
& \text { concentration analyt }[\mathrm{mg} / \mathrm{ml}]= \\
& \frac{\text { concentration standard }\left[\frac{\mathrm{mg}}{\mathrm{ml}}\right] \times \text { Area analyt }}{\text { Area standard }}
\end{aligned}
$$

concentration analyt $[\%]=$

$$
\frac{\text { concentration analyt }\left[\frac{\mathrm{mg}}{\mathrm{ml}}\right] \times 100}{\text { concentration sample }\left[\frac{\mathrm{mg}}{\mathrm{ml}}\right]}
$$




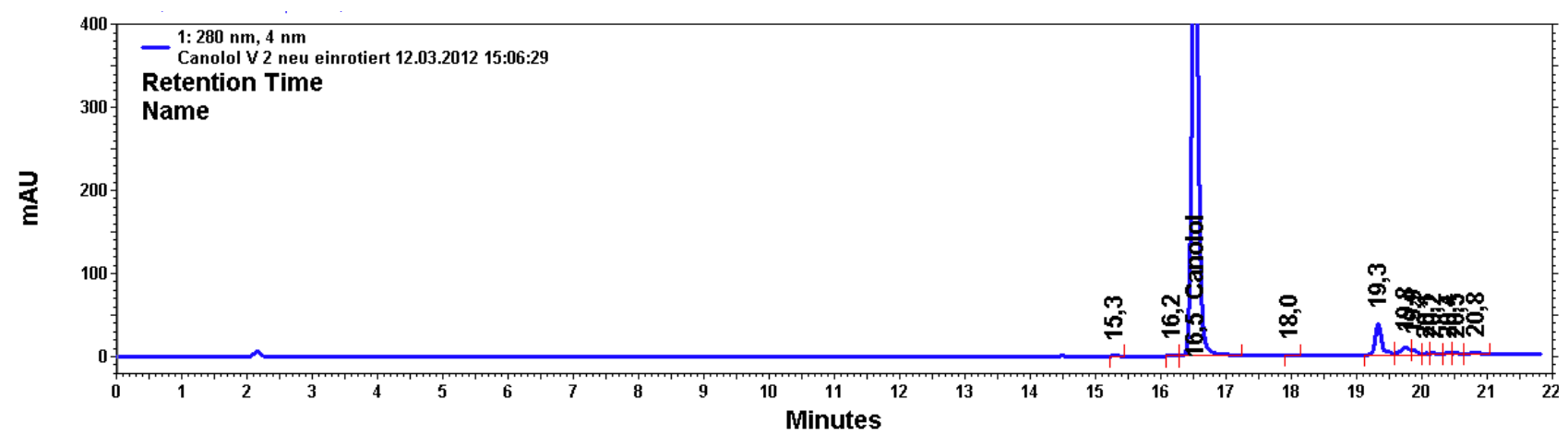

(a)

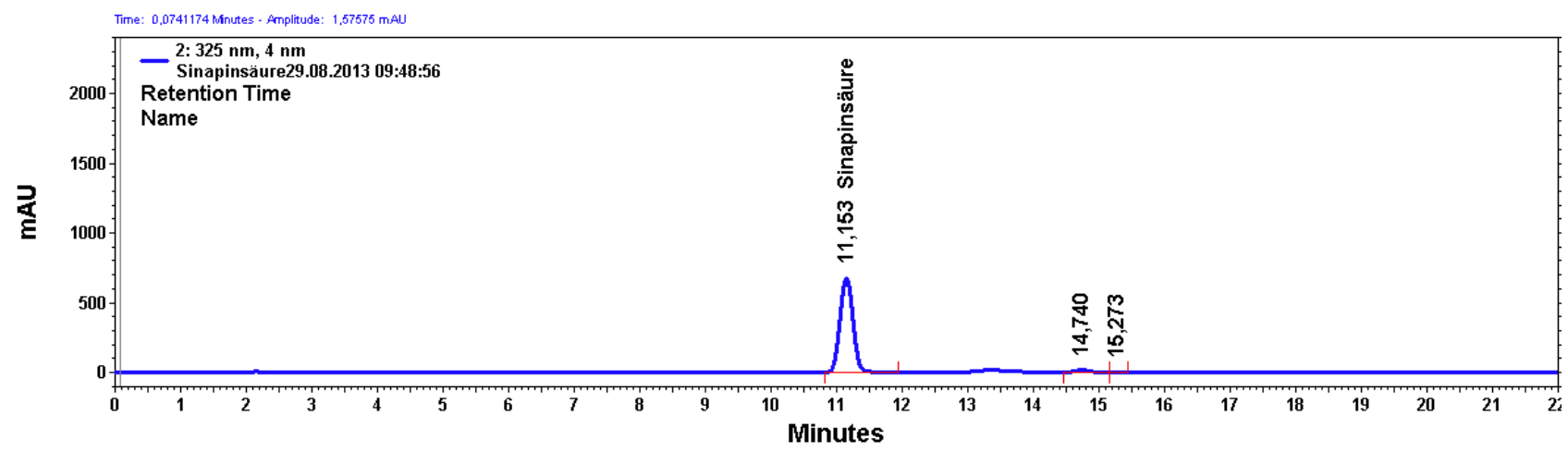

(b)

Fig. 3. Chromatogram of (a) the canolol standard (280 nm), (b) of the sinapic acid standard ( $325 \mathrm{~nm})$.
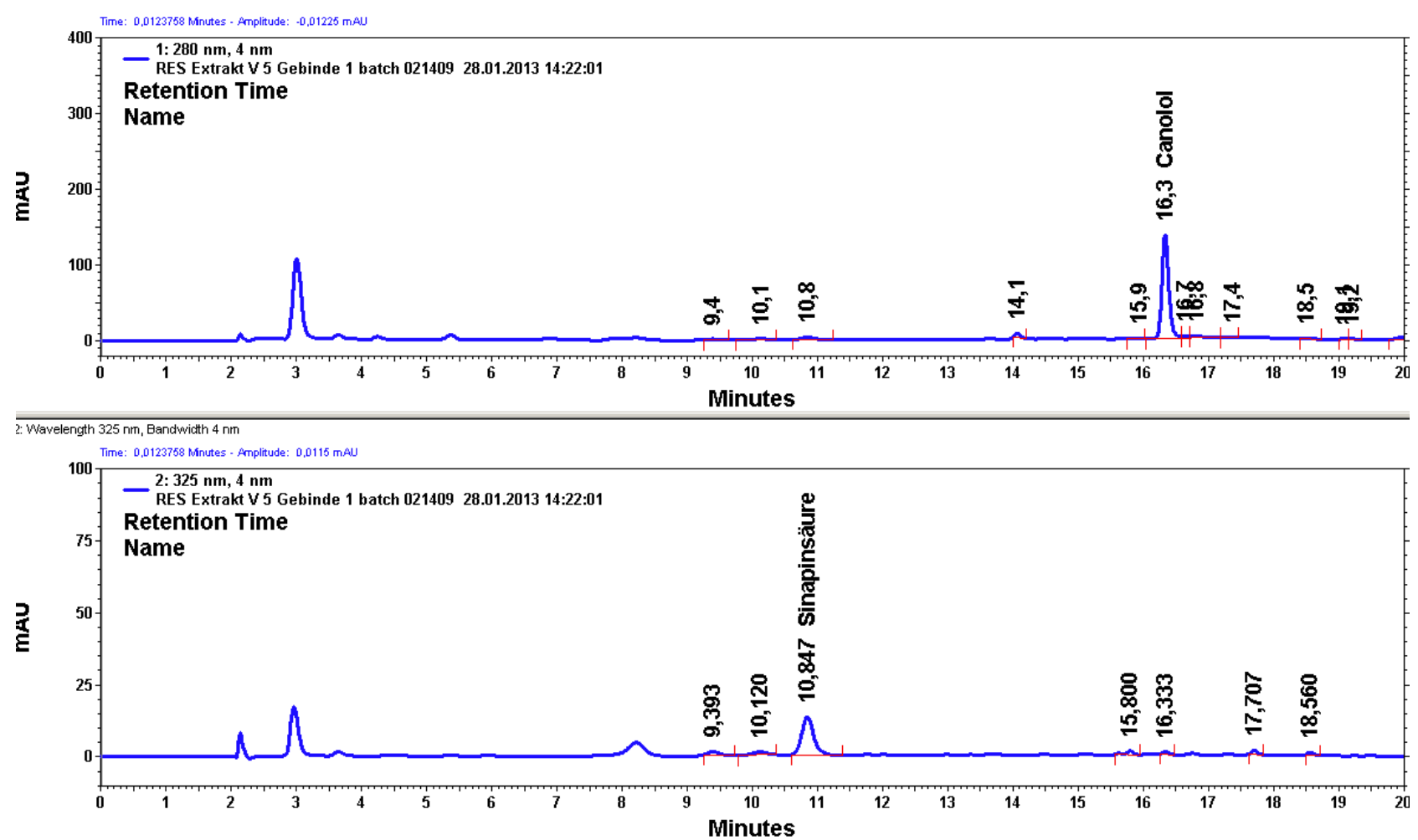

Fig. 4. Chromatogram of the extract (280 $\mathrm{nm}$ and $325 \mathrm{~nm})$. 
Table 2. Chromatographic conditions of the RP-DAD-HPLC method.

\begin{tabular}{|c|c|}
\hline Method parameters & HPLC3/DAD-HPLC \\
\hline HPLC-device & $\begin{array}{l}\text { Merck Hitachi, (VWR LaChrome Elite), pump L-2130; } \\
\text { autosampler L-2200 }\end{array}$ \\
\hline Data system & EZChrom Elite Version 3.3.2 SP2 Build 3.3.2 1037 \\
\hline HPLC column: & Lichrospher ${ }^{(\mathbb{R}} 100 \mathrm{RP}-18 \mathrm{e}(5 \mu \mathrm{m}), 250-4 \mathrm{~mm}$ \\
\hline Pre column: & Lichrospher $^{(\mathbb{R}} 100 \mathrm{RP}-18 \mathrm{e}(5 \mu \mathrm{m}), 4-4 \mathrm{~mm}$ \\
\hline Eluent: & $\begin{array}{l}\text { Eluent A: Water acidified with } o \text {-Phosphoric Acid } \\
(\mathrm{pH} 2,3-2,6) \text {; eluent B: methanol (gradient grade) } \\
\text { Eluent B: Methanol (HPLC gradient grade) } \\
\text { Eluent: C: CAN:THF (4:1) (v:v) }\end{array}$ \\
\hline
\end{tabular}

\begin{tabular}{|c|c|c|c|c|}
\hline \multirow{10}{*}{ Eluent profil $(\mathrm{v} / \mathrm{v})$ : } & $\min$ & $\mathrm{A}[\%]$ & $\mathrm{B}[\%]$ & Flow $[\mathrm{ml} / \mathrm{min}]$ \\
\hline & 0.00 & 70 & 30 & 1.0 \\
\hline & 5.00 & 70 & 30 & 1.0 \\
\hline & 15.00 & 30 & 70 & 1.0 \\
\hline & 20.00 & 10 & 90 & 1.0 \\
\hline & 23.00 & 10 & 90 & 1.0 \\
\hline & 23.10 & 0 & 100 & 1.0 \\
\hline & 25.00 & 0 & 100 & 1.0 \\
\hline & 25.10 & 70 & 30 & 1.0 \\
\hline & 30.00 & 30 & 70 & 1.0 \\
\hline Detector (wavelenght): & \multicolumn{4}{|c|}{$\begin{array}{l}\text { DAD-detektor Hitachi L-2455, Channels: } \lambda_{1}=280 \mathrm{~nm} \text {, } \\
\lambda_{2}=325 \mathrm{~nm}\end{array}$} \\
\hline Column temperature: & \multicolumn{4}{|c|}{ Column oven VWR Hitachi L-2350 $\left(35^{\circ} \mathrm{C}\right)$} \\
\hline Injection volume: & \multicolumn{4}{|c|}{ Standard: $10 \mu \mathrm{l}$ Probe: $10 \mu \mathrm{l}$} \\
\hline Method name & \multicolumn{4}{|c|}{ Sinapinsäure_Canolol.met } \\
\hline
\end{tabular}

\section{Results and discussion}

\subsection{Influence of inert gas}

During roasting in lab and small pilot scale initially inert gas (nitrogen) was used as fluidization medium to avoid oxidation. Since this would make a scale-up to an industrial process more expensive it was also proved whether ambient air (or a mixture of air and nitrogen) would be applicable. Therefore some trial series with different contents of (air) oxygen were carried out. The data shown in Figure 5 are based upon the following processing parameters: heating-up the fluidized bed up to $160^{\circ} \mathrm{C}\left(165^{\circ} \mathrm{C}\right.$ in case of no use of nitrogen, respectively), switching-off the heater after reaching this temperature and further fluidizing up to sampling. It can be seen, that there are no advantages of the use of nitrogen (Fig. 5).

\subsection{Influence of roasting temperature}

As described above the optimal temperature for the formation of canolol during roasting of rapeseed is $160{ }^{\circ} \mathrm{C}$ (Spielmeyer, 2007) or $165{ }^{\circ} \mathrm{C}$ (Wakamatsu, 2005), respectively. The present investigation shows that this is also valid for roasting of rapeseed meal or cake in a fluidized bed (Fig. 6).

\subsection{Influence of roasting time}

Additionally it was investigated how further roasting after reaching the optimal roasting temperature influences the

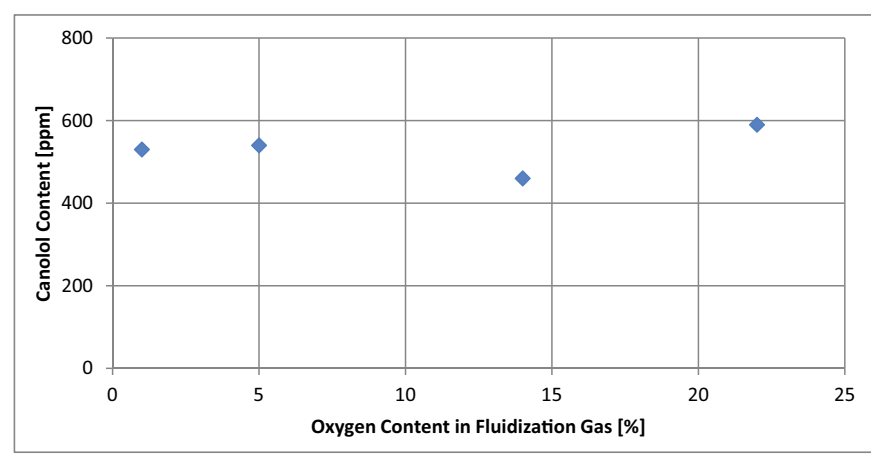

Fig. 5. Influence of oxygen content of fluidization gas on canolol content.

canolol content. Both trials using rapeseed meal and cake were made. Figure 7 shows that the canolol content is reduced with further roasting time. The reactions responsible for this effect are not clarified. It is also not clear, whether and to which extend during further roasting sinapic acid keeps on transforming into canolol.

Spielmeyer et al. also described the effect of the reduction of the canolol content during further roasting of rapeseed. They assumed that the formed canolol reacts with other rapeseed components or that pyrolysis or thermal degradation of canolol occurs (Spielmeyer, 2009).

Furthermore it could be observed that the kind of coolingdown of the roasted material has influence on the resulting 


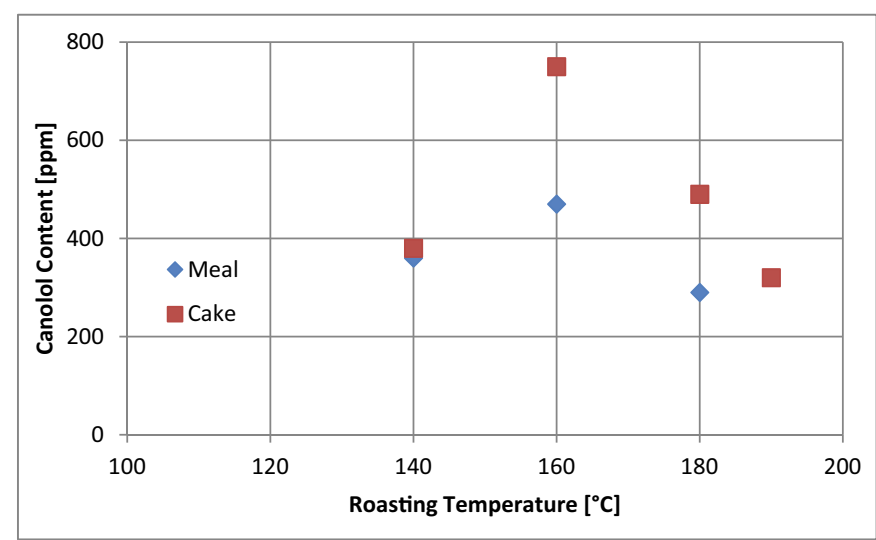

Fig. 6. Dependency of canolol content in roasted rapeseed meal and cake on roasting temperature.

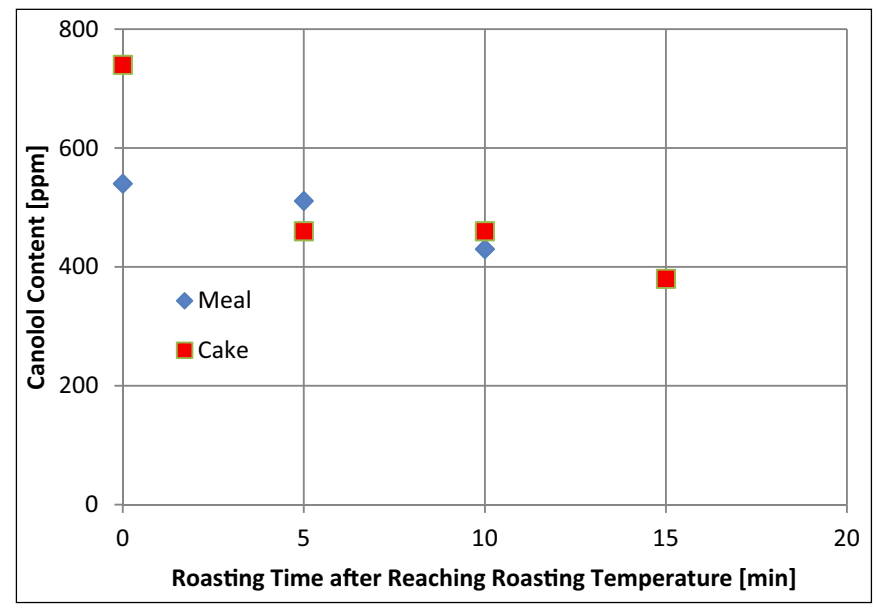

Fig. 7. Influence of further roasting on canolol content.

canolol content. It is considerably lower if the material is slowly cooled-down after reaching the optimal roasting temperature and sampling (e.g. by storage in an open container) in comparison to fast cooling-down (e.g. by active heat exchange). From this follows that it would be ideal to use two fluidized beds in a row. In the first one the material is quickly heated-up to the optimal roasting temperature and immediately after reaching that it is rapidly cooled-down in the second one.

\subsection{Influence of particle size}

Due to the stability criteria of a fluidized bed commercial rapeseed meal just as commercial press cake is not applicable in fluidized bed equipments. The velocity of the fluidization medium has to be higher than the minimum fluidized velocity of the biggest particles below that a fixed bed occurs and lower than the fluctuation velocity of the smallest particles above that the pneumatic transport begins. Commercial material is very heterogeneous in terms of its particle size. Therefore at least a previous milling is required. In preliminary lab scale tests it was determined that the particle size should be between 0.5 and $0.8 \mathrm{~mm}$ to make sure a stable fluidized bed.

Moreover it was to clarify whether the particle size would influence the canolol content after roasting. To investigate that,

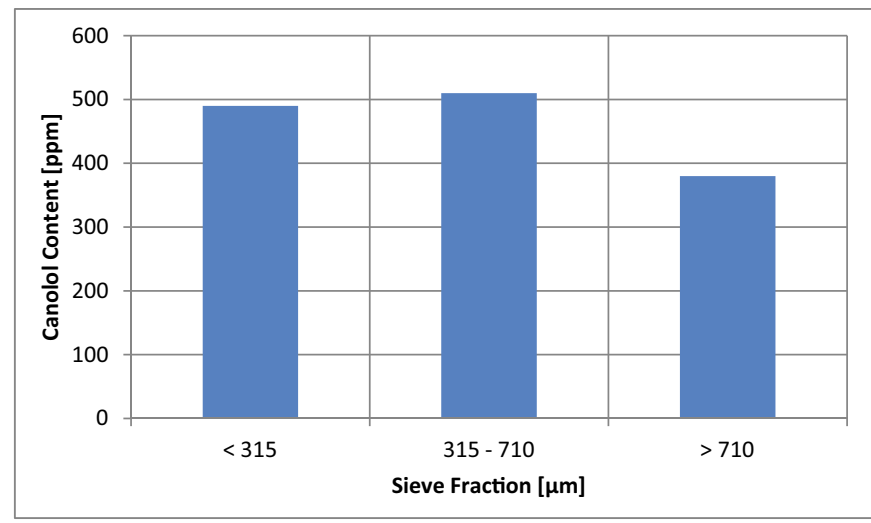

Fig. 8. Canolol content of different fractions of roasted rapeseed meal.

roasted rapeseed meal was sieved into three fractions $(3.4 \%<$ $315 \mu \mathrm{m}, 91.9 \% 315-710 \mu \mathrm{m}, 4.7 \%>710 \mu \mathrm{m})$ and the canolol content of each fraction was analyzed. It can be seen in Figure 8 that the canolol content of the fraction $>710 \mu \mathrm{m}$ is clearly lower than that of the other two fractions. That means there is a reduction of the canolol content with increasing particle size.

This could be confirmed by analyzing the fine particles which were collected in the filter. Their canolol content was partially much higher than that of the roasted product. That could be explained by their short residence time in the reactor before leaving. Another reason could be that the small particles enable a better heat and mass transfer which accelerate the drying process and shorten the time to reach the optimal roasting temperature.

\subsection{Achievable canolol content}

In the lab and small pilot scale trials canolol contents of the roasted rapeseed meal of about $500 \mathrm{mg} / \mathrm{kg}$ were achieved. The initial canolol content in the meal was about $300 \mathrm{mg} / \mathrm{kg}$, whereas the sinapic acid concentration was between 600 and $1.000 \mathrm{mg} / \mathrm{kg}$. It is essential to realize that sinapic acid could only partially be transferred into canolol.

Therefore it was tried to reach higher canolol contents within the roasting product by intensifying heat and mass transfer which would lead simultaneously to better cost effectiveness of the process.

As one possibility to do this the use of a superheated steam fluidized bed was deemed. Use of superheated steam instead of air or nitrogen leads to faster drying and heating-up. In order to avoid the canolol reducing reactions after reaching the optimal roasting temperature the material was immediately conveyed into a second fluidized bed equipment in which it was cooled-down to $50{ }^{\circ} \mathrm{C}$ by ambient air. The steam input temperature, the amount of rapeseed meal (hold-up) and the level of the steam output temperature at which the roasting procedure is interrupted, which correlates with the roasting temperature, were varied. However, Figure 9 shows that the achieved canolol contents were not higher in comparison to gas fluidization. The named process parameters seem to have only little influence on the result.

Finally up-scaling into the next bigger scale was done (industrial trials). The used fluidized bed reactor was equipped 


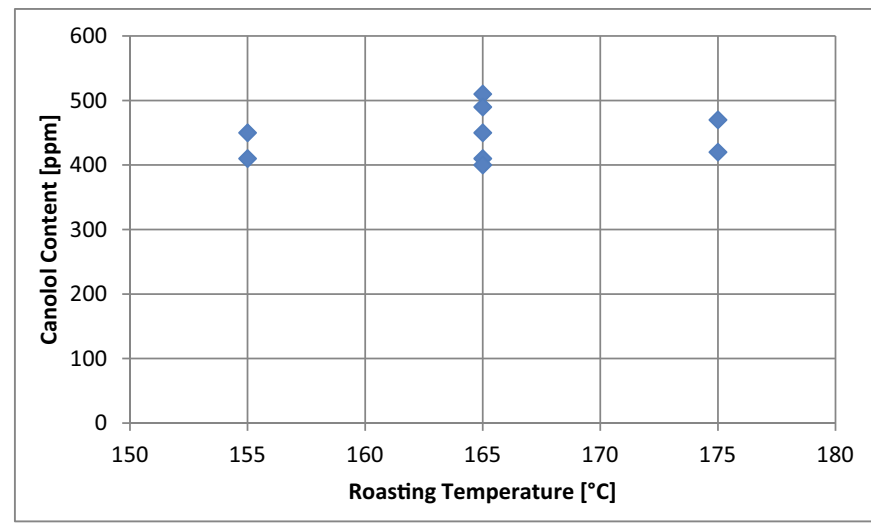

Fig. 9. Canolol content at different roasting temperatures in a steam fluidized bed.

Table 3. Processing parameters of industrial trials.

\begin{tabular}{cccc}
\hline & & 1st trial & 2nd trial \\
\hline Hold-up & $\mathrm{kg}$ & 30 & 30 \\
\hline Input air temperature & ${ }^{\circ} \mathrm{C}$ & 180 & 200 \\
\hline Heat exchanger temperature & ${ }^{\circ} \mathrm{C}$ & $165-175$ & $170-180$ \\
\hline Heating-up time & $\mathrm{min}$ & 30 & 22 \\
\hline
\end{tabular}

with pipe bundles immerging into the fluidized bed. To fluidize the material air was used. $30 \mathrm{~kg}$ of rapeseed meal per batch were roasted. After reaching $165^{\circ} \mathrm{C}$ within the material the heat exchangers were switched off and the fluidized bed was further operated using ambient air. The trials were finished at $90{ }^{\circ} \mathrm{C}$ material temperature (after about $25 \mathrm{~min}$ ). The other trial parameters are shown in Table 3.

The canolol content of the roasted product was $470 \mathrm{mg} / \mathrm{kg}$ (1st trail) and $500 \mathrm{mg} / \mathrm{kg}$ (2nd trial), respectively. The results from the lab and pilot scale trials could be confirmed, but in average not achieved or even exceeded. The dimension of the used equipment caused a bigger response time of the heatingup and cooling-down processes. It can be concluded that during the whole roasting process already degradation reactions happen which influence the total result negatively.

\subsection{Relationsship between canolol and sinapic acid content}

If it is assumed that canolol is formed from sinapic acid, the sinapic acid content should decrease during roasting to the same extent as the canolol content increases. However, it could be observed (although not in every case) that the sinapic acid content of the roasted material was higher, than it should be according to these considerations. Figure 10 shows this for the carried out industrial trials exemplarily. The roasting time of the 1 st trial was shorter than that of the 2 nd trial.

That raises the presumption that sinapic acid is reproduced during roasting. But, the proceeding reactions are not known.

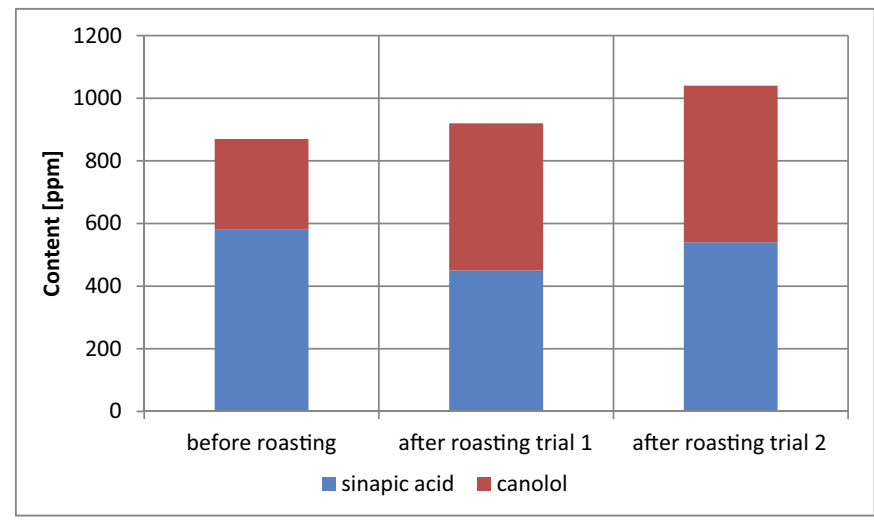

Fig. 10. Canolol and sinapic acid content before and after roasting.

\section{Conclusions}

In summary, it can be concluded:

- Roasting of rapeseed meal or cake in a fluidized bed is a suitable technology to transfer sinapic acid into canolol.

- The achievable canolol contents are of about $500 \mathrm{mg} / \mathrm{kg}$ in the case of using rapeseed meal. In roasted rapeseed cakes (small pilot scale) more than $700 \mathrm{mg} / \mathrm{kg}$ canolol could be determined. The initial amount of sinapic acid in the raw material is only partially transformed into canolol, even under optimal conditions.

- The application of an inert fluidization medium is not necessary. The use of air does not influence the canolol formation negatively.

- The optimal roasting temperature is $165^{\circ} \mathrm{C}$.

- The roasting process has to be interrupted immediately after reaching the optimal roasting temperature. The faster the roasted material is cooled-down the higher is its canolol content. Further roasting reduces the canolol content, probably due to degradation reactions which are not studied. Possibly the formed degradation products possess also antioxidant properties.

- Smaller particles show higher canolol contents after roasting than bigger ones. The reasons are suspected in the averaged shorter residence time within the fluidized bed reactor and the improved heat and mass transfer due to faster drying. In order to secure a stable operation regime the material should be milled to $<0.8 \mathrm{~mm}$ before roasting.

- Acceleration of heating-up by using of additional heat exchangers immerging in the fluidized bed or by applying superheated steam as fluidization medium improves the effectiveness of the process, but has no significant influence on the canolol formation and yield.

It was observed, that the sinapic acid content was not decreased in the same amount as the canolol content increased. A re-production of sinapic acid during roasting seems to happen. The reaction mechanisms are not known. In terms of improving the canolol production technology it should be worthwhile to clarify these and to find ways to promote this re-production of sinapic acid and to enable their transforming into canolol. 
Acknowledgements. Sponsored by Bundesministerium für Wirtschaft und Technologie aufgrund eines Beschlusses des Deutschen Bundestages, Projekt-No. KF2023912.

\section{References}

Artz WE, Swanson BG, Sendzicki J, Rasyid A, Birch REW. 1986. ACS Symposium Series 312, RL Ory, Ed. Washington: American Chemical Society, pp. 126-137.

Baumert A, Milkowski C, Schmidt J, Nimtz M, Wray V, Strack D. 2005. Formation of a complex pattern of sinapate esters in Brassica napus seeds catalyzed by enzymes of serine carboxypeptidase-like acyltransferase family. Phytochem. 66: 1334-1345.

Eggers R, Ambrogi A. 2003. Kurzzeitige Hochtemperaturbehandlung zur Konditionierung bei der Verarbeitung von Ölsaaten. FEIKurzbericht. AiF $12781 \mathrm{~N}$.

Eggers R. 2006. Raffination begleitkomponentenreicher Rapsöle. FEI-Kurzbericht. AiF 13832 N.

Eggers R, Schwarz K. 2010. Polyphenolangereichertes Deodestillat zur Erhöhung der Oxidations-stabilität von speiseölhaltigen Nahrungsmitteln. FEI-Kurzbericht. AiF 15216 N.

Fenwick RG, Hoggan SA. 1976. The tannin content of rapeseed meal. Br. Poult. Sci. 17: 59-62.

Fenwick, GR, Curl CL, Butler EJ, Greenwood NM, Pearson AW. 1984. Rapeseed meal and egg taint: effects of low glucosinolate Brassica napus meal, dehulled meal and hulls and of neomycin. J. Sci. Food Agric. 35: 749-756.

Koski A, Pekkarinen S, Hopia A, Wähälä K, Heinonen M. 2003. Processing of rapeseed oil: Effects on sinapinic acid derivative content and oxidative stability. Eur. Food Res. Technol. 217: $110-114$.

Krygier K, Sosulski F, Hogge L. 1982. Free, esterified and insoluble phenolic acids. II. Composition of phenolic acids in rapeseed flour and hulls. J. Agric. Food Chem. 30: 334-336.

Kuwahara H, Kanazanwa A, Wakamatu D, Morimura S, Kida K, Akaike T, Maeda H. 2004. Antioxidative and antimutagenic activities of 4-vinyl-2,6-dimethoxyphenol (Canolol) isolated from canola oil. J Agric Food Chem 52: 4380-4387.

Matthäus B. 1998. Effect of dehulling on the composition of antinutritive compounds in various cultivars of rapeseed. Fett/Lipid 100: 295-301.
Matthäus B, Pudel F, Leidt K-H. 2012. Canolol formation during fluidized bed treatment of rapeseed meal, 10th Euro Fed Lipid Congress, 23-26 September 2012, Cracow, Poland.

Matthäus B, Pudel F, Leidt K-H, Habicht V, Quirin K-W, Cawelius A. 2013. Fluidized bed treatment of rapeseed meal as possibility for the production of canolol, 4th Leipzig Symposium "Rapeseed - Tremendous Potential for added Value Generation?" 20-21 March 2013. Leipzig, Germany.

Moltke Sørensen AD, Friel J, Winkler-Moser J K, Jacobsen C, Huidrom D, Reddy N, Thiyam-Holländer U. 2013. Impact of endogenous canola phenolics on the oxidative stability of oil-inwater emulsions. Eur. J. Lipid Sci. Technol. 115: 501-512.

Müller MM, Ryl EB, Fenton T, Clandinin DR. 1978. Cultivar and growing location differences on the sinapine content of rapeseed. Can. J. Anim. Sci. 58: 579-583.

Naczk M, Amarowicz R, Sullivan A, Shahidi F. 1998. Developments on polyphenolics of rapeseed/canola: A Review. Food Chem. 62: 489-502.

Nowak H, Kujawa K, Zadernowski R, Roczniak B, Kozlowska H. 1992. Antioxidative and bactericidal properties of phenolic compounds in rapeseeds. Fat Sci. Technol. 94: 149-152.

Pudel F, Habicht V, Matthäus B, Quirin K-W, Cawelius A. 2013. Production of canolol by fluidized bed roasting and $\mathrm{CO}_{2}$ extraction of rapeseed meal. 104th AOCS Annual Meeting \& Expo, April 28-May 1, 2013, Montréal, Québec, Canada.

Qiao HY, Dahiya JP, Classen HL. 2008. Nutritional and physological effects of dietary sinapic acid (4-hydroxy-3,5-dimethoxycinammic acid) in broiler chickens and its metabolism in the digestive tract. Poultry Sci. 87: 719-726.

Spielmeyer A, Wagner A, Jahreis G. 2009. Influence of thermal treatment of rapeseed on the canolol content. Food Chem. 112: 944 948.

Thiyam U, Stöckmann H, zum Felde T, Schwarz K. 2006. Antioxidative effect of the main sinapic acid derivates from rapeseed rapeseed and mustard oil by-products. Eur. J. Lipid Sci. Technol. 108: 238-248.

Wakamatsu D, Morimura S, Sawa T, Kida K, Nakai C, Maeda H. 2005. Isolation, identification, and structure of a potent alkylperoxyl radical scavenger in crude canola oil, canolol. Biosci. Biotechnol. Biochem. 69: 1568-1574.

Cite this article as: Frank Pudel, Volkmar Habicht, Thomas Piofczyk, Bertrand Matthäus, Karl-Werner Quirin, Anja Cawelius. Fluidized bed treatment of rapeseed meal and cake as possibility for the production of canolol. OCL 2014, 21(1) D103. 